\title{
CORRELATIONS BETWEEN CLINICAL PARAMETERS AND HEALTH-RELATED QUALITY OF LIFE IN POSTMENOPAUSAL OSTEOPOROTIC WOMEN
}

Vesna Grbovic ${ }^{1}$, Aleksandra Jurisic Skevin ${ }^{1}$, Katarina Parezanovic Ilic ${ }^{1}$, Aleksandra Lucic Tomic ${ }^{2}$, Jasmin Nurkovic ${ }^{3}$, Dejan Jeremic ${ }^{4}$, Dusica Djordjevic ${ }^{1}$ ${ }^{1}$ Department of Physical Medicine and Rehabilitation, Faculty of Medical Sciences, University of Kragujevac, Serbia ${ }^{2}$ Department of Internal Medicine, Faculty of Medical Sciences, University of Kragujevac, Serbia ${ }^{3}$ Department of Biomedical Sciences, State University of Novi Pazar, Serbia

${ }^{4}$ Department of Anatomy, Faculty of Medical Sciences, University of Kragujevac, Serbia

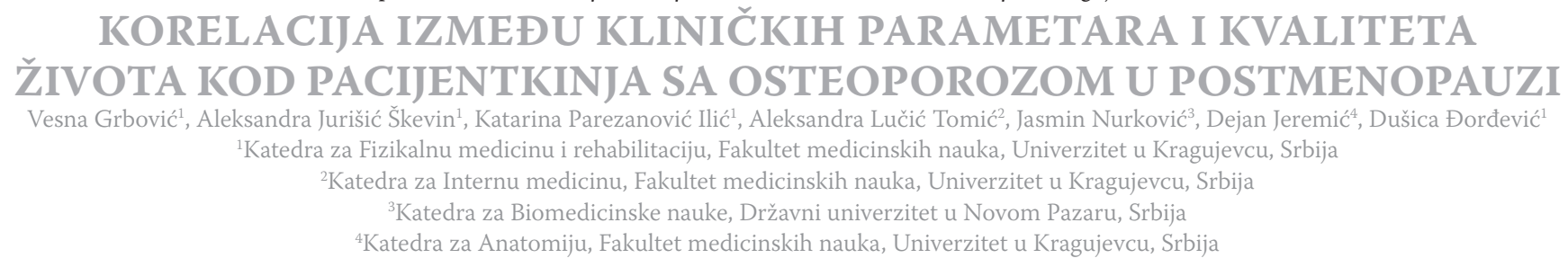

Received / Primljen: 03.03.2016.

Accepted / Prihvaćen: 07.04.2016

\section{ABSTRACT}

The purpose of this study was to assess the correlation between health-related quality of life (HRQoL) and clinically relevant osteodensitometric and biochemical parameters in postmenopausal osteoporotic women. Bone mineral density (BMD) and $T$ scores of the lumbar vertebrae and femoral neck were assessed in 100 osteoporotic women (56 without previous fractures and 44 with previous fractures) using dual $x$-ray absorptiometry. The Fracture Risk Assessment Tool (FRAX) index for major osteoporotic and hip fractures was calculated based on demographic data and hip BMD. Venous blood samples were taken from each subject for biochemical analysis (serum calcium, phosphorus, alkaline phosphatase and vitamin D levels). HRQoL was assessed using the QUALEFFO-41 questionnaire (domains: Health perception, Pain, and Physical, Social and Mental function). Basic participant characteristics (age, menopause length, body mass index, smoking habits, hereditary tendency towards fracture, fracture history) correlated with some of the QUALEFFO-41 domains, but the correlation coefficients were low $(r<0.3)$, except in the case of the correlation between Pain and fracture history $(r=0.638)$. Of the six variables included in the multiple regression model, fracture history was shown to be the most significant predictor with respect to the following three QUALEFFO-41 domains: Pain $(b=20.511)$, Social function $(b=2.548)$ and Health perception $(b=3.185)$. Correlation analysis showed that after adjustment for basic characteristics, $B M D$ and $T$ score of the femoral neck and Pain ( $r=0.331$ and $r=0.449$, respectively), Social function $(r=0.422$ and $r=0.419)$ and Health perception ( $r=0.434$ for $T$ score of the femoral neck) exhibited the strongest correlations. Vitamin D was negatively correlated with Mental function, while the other biochemical parameters exhibited variable correlations with the QUALEFFO-41 domains ( $r \approx 0.2-0.5)$. Our study confirmed the previously established relationship between BMD of the femoral neck and HRQoL in patients with osteoporosis and demonstrated correlations between various blood bone metabolism parameters and HRQoL that have not been previously investigated.

Keywords: osteoporosis; quality of life; bone mineral density; FRAX; Vitamin D

\section{SAŽETAK}

Cilj studije bio je pronalaženje korelacija između kvaliteta života postmenopauzičnih pacijentkinja sa osteoporozom $i$ klinički relevantnih osteodenzitometrijskih $i$ biohemijskih parametara. Mineralna gustina kostiju i T skor u nivou lumbalne kičme $i$ vrata butne kosti mereni su, putem dvoenergetske apsorpciometrije X zracima, na uzorku od 100 osteoporotičnih žena. Procena rizika od nastanka glavnih osteoporotičnih fraktura i frakture kuka je vršena na osnovu demografskih podataka i mineralne gustine kosti u nivou vrata butne kosti (FRAX indeks). Svakoj pacijentkinji je uzet uzorak venske krvi radi biohemijskih analiza (serumski nivoi kalcijuma, fosfora, alkalne fosfataze $i$ vitamina D). Kvalitet života procenjen je na osnovu QUALEFFO-41 upitnika (domeni: Percepcija zdravlja, Bol, Fizičko, Socijalno i Mentalno funkcionisanje). Bazične karakteristike pacijentkinja (starost, trajanje menopauze, indeks telesne mase, pušenje, pozitivan hereditet za frakturu butne kosti, prethodna fraktura) korelirale su sa nekim domenima QUALEFFO-41 upitnika, ali su koeficijenti korelacije bili niski $(r<0.3)$, osim u slučaju veze između domena Bol i prethodne frakture ( $r=0.638)$. Od ovih šest odabranih prediktivnih varijabli u modelu multiple regresije, prethodna fraktura se pokazala kao najznačajnija prediktivna varijabla za tri QUALEFFO-41 domena: Bol $(b=20.511)$, Socijalna funkcija $(b=2.548)$ i Percepcija $z$ dravlja $(b=3.185)$. Korelaciona analiza je pokazala da su, nakon prilagođavanja bazičnim karakteristikama ispitanica, najjače korelacije pronađene između mineralne gustine kosti $i$ T skora $u$ nivou vrata butne kosti $i$ domena Bol $(r=0.331$ and $r=0.449$, respektivno), Socijalna funkcija $(r=0.422$ i $r=0.419)$ i Percepcija $z$ dravlja ( $r=0.434$ za T skor u nivou vrata butne kosti). Vitamin D je negativno korelirao sa domenom Mentalna funkcija, dok su drugi biohemijski parametri sporadično korelirali sa domenima QUALEFFO-41 ( $r \approx 0.2-0.5)$. Rezultati naše studije potvrđuju vezu između mineralne gustine kosti u nivou vrata butne kosti i kvaliteta života pacijentkinja sa osteoporozom, $i$ ukazuju na korelacije izmedu biohemijskih parametara koštanog metabolizma u krvi i kvaliteta života, što u ranijim studijama nije ispitivano.

Ključne reči: osteoporoza; kvalitet života; mineralna gustina kosti; FRAX indeks; vitamin D 


\section{$\theta 0$}

\section{ABBREVIATIONS}

BMD - Bone Mineral Density

DXA - Dual X-ray Absorptiometry

FRAX - Fracture Risk Assessment Tool

FRAX FNF - FRAX index for Femoral Neck Fracture
FRAX MOF - FRAX index for Major Osteoporotic Fracture HRQoL - Health-Related Quality of Life

QoL - Quality of Life

QUALEFFO - Quality of Life Questionnaire of the European Foundation for Osteoporosis

\section{INTRODUCTION}

Osteoporosis is a condition characterized by systemic microarchitectural deterioration of bone tissue, impairments of bone mass and strength, and increases in bone fragility and fracture susceptibility (1). Osteoporosis and its associated fractures have been documented for many years and have commonly been viewed as inevitable consequences of the ageing process (2). Given the current prevalence of the condition (3) the ageing of the population, and the clinical, economic, and social aspects of the disease, osteoporosis may be considered an emerging major public health burden $(2,4)$.

Low bone mineral density (BMD) is one of the most significant risk factors for fracture (3). BMD can be assessed with dual x-ray absorptiometry (DXA), and osteoporosis is defined as a BMD of 2.5 standard deviations or more below peak bone mass, which is represented by the $\mathrm{T}$ score (5). Some new fracture risk assessment tools have been developed (6), including the World Health Organization fracture risk assessment tool (FRAX index), an algorithm that integrates clinical risk factors with BMD to predict an individual's 10-year risk of sustaining a hip fracture or another major osteoporotic fracture $(7,8)$. Although osteoporosis may exist without fractures in many individuals, in postmenopausal women, osteoporotic fractures typically occur in the distal forearm, the spine and the upper femur (9). From a patient perspective, fractures and the subsequent loss of mobility and autonomy caused by fractures often result in a major decrease in quality of life (QoL). Thus, QoL measures have gained increasing attention as clinically relevant patient-centred endpoints in clinical trials (10).

The effects of osteoporosis and osteoporosis-related fractures on QoL are commonly assessed using health-related QoL (HRQoL) tools, such as the Quality of Life Questionnaire of the European Foundation for Osteoporosis (QUALEFFO) (11). The relationship between HRQoL and osteoporotic fracture has been extensively researched and reviewed (12), while the relationship between HRQoL and osteoporosis without fractures has been investigated in only a few studies, the results of which are ambiguous $(9,13)$. It has been suggested that patients often experience pain with osteoporosis even before fractures occur (13). This pain may be related to fatigue or bone microarchitectural failure, which may be associated with low BMD (14). The available literature shows that BMD of the upper femur is correlated with some HRQoL domains $(10,15)$, while the relationship between HRQoL and BMD of the lumbar spine is not as clear $(15,16)$.

Vitamin D plays a critical role in bone metabolism (17); thus, its deficiency represents a major determinant of osteoporosis fracture risk (18-21). It has been reported that inadequate serum vitamin D levels are associated with low calcium absorption, secondary hyperparathyroidism, increased bone turnover, bone loss and low BMD (17, 21-23). The increase in fracture risk caused by inadequate vitamin D levels is not merely the result of decreases in BMD. In recent years, vitamin D deficiency has been associated with loss of muscle mass, muscle weakness, and musculoskeletal pain (24-27), all of which significantly contribute to falls. Generally, little is known regarding the relationship between serum vitamin D levels and HRQoL in osteoporosis, but a very recent study suggested that low serum vitamin D levels were a significant determinant of HRQoL in osteoporotic women independent of the conventional factors that reduce HRQoL (28).

The aim of our research was to assess the correlations between HRQoL and clinically relevant osteodensitometric (BMD and $\mathrm{T}$ scores of the lumbar spine and femoral neck and FRAX indices of the hip and other major osteoporotic fractures) and biochemical parameters (serum calcium, phosphorus, alkaline phosphatase and vitamin D levels) in postmenopausal osteoporotic women. We also aimed to explore the influences of basic subject characteristics, especially fracture history, on osteoporotic patient quality of life.

\section{PATIENTS AND METHODS}

This cross-sectional study included a group of 100 osteoporotic patients ( 56 without a history of fracture and 44 with a history of fracture) from the Clinical Centre Kragujevac, Serbia. Data collection was performed from January to December 2012.

The study was approved by the Ethics Committee of the Clinical Centre Kragujevac. After being informed of the study's purpose, risks and benefits, all patients provided written informed consent to participate in the study.

Diagnoses of osteoporosis (T score $\leq-2.5$ ) were based on the results of DXA scans performed by an experienced rheumatologist using a Discovery TM osteodensitometer 
(Hologic, Bedford, MA). Patients with secondary osteoporosis or some other chronic disease affecting quality of life (tumour, chronic renal failure, chronic pulmonary insufficiency, cardiovascular disease, uncontrolled hypertension, diabetes, rheumatoid arthritis, and severe hearing, vision, and cognitive function disturbances), as well as patients receiving glucocorticoids and patients with a history of fracture within the last 6 months, were excluded from the study.

The study comprised the following steps: 1) anamnesis (age, menopause occurrence and length, fracture occurrence, hereditary tendency towards fracture, smoking habits, and alcohol consumption), 2) patients completed the QUALEFFO-41 questionnaire (the questionnaire was described and validated for use in Serbian populations by Tadic and colleagues (29)), 3) patients underwent osteodensitometric measurements (BMD, $\mathrm{T}$ score) of the femoral neck (BMD FN, T score FN) and lumbar vertebrae (BMD LV, T score LV), 4) patients underwent anthropometric measurements (body mass index (BMI)), 5) patient 10-year fracture risks (FRAX index) for major osteoporotic fracture (spine, forearm, hip or shoulder fracture; FRAX MOF) and femoral neck fracture (FRAX FNF) were calculated based on the data obtained using the abovementioned measurements and a computer program (30), and 6) patients provided blood samples for biochemical analysis (serum vitamin D (Vit D), calcium (Ca), phosphorus (P), alkaline phosphatase (ALP)), which was performed using routine methods in the Central Laboratory of the Clinical Centre Kragujevac.

The QUALEFFO-41 questionnaire comprises the following five domains (41 items in total): Pain (5 items), Physical function (17 items), Social function (7 items), Health perception (3 items) and Mental function (9 items). Most of the items have 5 answer options, although some have 3 or 4 answer options. Most items are scored in reverse order, i.e., the lowest number on the scale corresponds to the best answer, and the highest number corresponds to the worst answer (with the exception of 6 items). The score for each domain is calculated as the average value of all the answered items, which are linearly transformed on a scale of 0-100. Higher scores are indicative of worse HRQoL.

Statistical analysis was performed using SPSS 19.0 for Windows. Data were analysed using two independent samples tests, bivariate correlation, partial correlation and multiple linear regression. The results are expressed as means \pm standard deviations and as numbers and percentages. The alpha level for significance was set to $p<0.05$.

\section{RESULTS}

Correlation and multiple regression analyses were conducted to examine the relationships between QUELEFFO-41 domains and basic patient characteristics. Tables 1 summarize the descriptive statistics and analysis results.
As seen in Table 1, all parameters except hereditary tendency towards fracture were significantly correlated with the Pain domain, but the coefficients of those correlations were poor, except in the case of fracture history, whose relationship with the Pain domain was moderately strong. The multiple regression model significantly predicted Pain scores based on fracture history after adjustment for the other variables included in the model, indicating that patients with fracture histories were likely to have higher Pain scores. Two independent samples tests showed that patients without and with fracture histories differed significantly with respect to their scores in this domain $(45.53 \pm 8.97$ vs $65.45 \pm 15.98, \mathrm{P}=0.000)$. No other osteodensitometric variables contributed to the multiple regression model.

Physical function domain scores were not significantly correlated with any basic patient characteristics, and the multiple regression model did not significantly predict the score of this domain.

Regarding the Social function domain, body mass index was significantly negatively associated with social function, and fracture history was positively correlated with social function; however, the strength of this correlation was poor. The multiple regression model significantly predicted the score of this domain. Age exhibited significant negative regression weight, and fracture history exhibited positive regression weight; thus, after adjustment for the other variables in the model, older patients were expected to have lower Social function scores, while patients with fracture histories were expected to have higher Social function scores. Two independent samples tests showed that patients without and with fracture histories significantly differed with respect to their scores in this domain $(31.07 \pm 4.97 v s .33 .45 \pm 3.60, p=0.012)$.

Hereditary tendency towards fracture was negatively correlated with the Health perception domain, and fracture history was positively correlated with the Health perception domain (poor correlation strength). The multiple regression model significantly predicted the score in this domain. Patients with hereditary tendency towards fracture were expected to have lower Health perception scores, and patients with history of fracture were expected to have higher Health perception scores. Two independent samples test showed that patients without and with fracture histories significantly differed with respect to their scores in this domain $(31.21 \pm 5.21 v s .34 .63 \pm 7.01, p=0.006)$.

The Mental function domain was significantly correlated only with smoking (very low negative correlation). The multiple regression model did not significantly predict scores in this domain.

The mean scores that patients achieved in each QUELEFFO-41 domain are shown in Table 1, while the mean values of patient osteodensitometric parameters and biochemical parameters are shown in Table 2.

Correlation analysis (Table 3) showed that among the 100 osteoporotic women enrolled in this study, the Pain domain was significantly negatively correlated with $\mathrm{T}$ 
Table 1. Summary statistics, correlations and regression analysis results: a prediction model based on basic patient characteristics $\left({ }^{*} p<0.05\right)$.

\begin{tabular}{|c|c|c|c|c|c|}
\hline \multicolumn{6}{|c|}{ Prediction model: Basic participant characteristics } \\
\hline $\begin{array}{c}\text { Age } \\
(\mathrm{X} \pm \mathrm{SD})\end{array}$ & $\begin{array}{c}\text { Menopause } \\
\text { duration }(\mathrm{X} \pm \mathrm{SD})\end{array}$ & $\begin{array}{c}\mathrm{BMI} \\
(\mathrm{X} \pm \mathrm{SD})\end{array}$ & Smoking (no/yes) & $\begin{array}{c}\text { Hereditary tendency } \\
\text { towards fracture (no/yes) }\end{array}$ & Fracture history (no/yes) \\
\hline $65.39 \pm 7.69$ & $18.25 \pm 7.81$ & $24.59 \pm 2.85$ & $72 / 28$ & $94 / 6$ & $56 / 44$ \\
\hline \multicolumn{6}{|c|}{$\begin{array}{c}\text { Pain score }(\mathrm{X} \pm \mathrm{SD}): 54.166 \pm 16.256 \\
\mathrm{R}^{2}=0.428, \mathrm{~F}(6,89)=11.095, \mathrm{p}=0.000\end{array}$} \\
\hline \multirow{2}{*}{\multicolumn{2}{|c|}{ Variable }} & \multirow{2}{*}{ Correlation coefficient } & \multicolumn{3}{|c|}{ Multiple regression weights } \\
\hline & & & $\mathrm{b}$ & \multicolumn{2}{|r|}{$\beta$} \\
\hline \multicolumn{2}{|c|}{ Age } & $0.187^{*}$ & -0.308 & & -0.146 \\
\hline \multicolumn{2}{|c|}{ Menopause duration } & $0.174^{*}$ & 0.184 & \multicolumn{2}{|r|}{0.089} \\
\hline \multicolumn{2}{|c|}{ BMI } & $-0.330^{*}$ & -0.410 & \multicolumn{2}{|r|}{-0.072} \\
\hline \multicolumn{2}{|c|}{ Smoking } & $0.192^{*}$ & 0.091 & \multicolumn{2}{|r|}{0.003} \\
\hline \multicolumn{2}{|c|}{ Hereditary tendency towards fracture } & -0.168 & -5.482 & \multicolumn{2}{|r|}{-0.082} \\
\hline \multicolumn{2}{|c|}{ Fracture history } & $0.638^{*}$ & $20.511^{*}$ & & 0.629 \\
\hline & & $\begin{array}{l}\text { Physical function } \\
R^{2}=0.064, F(6,\end{array}$ & $\begin{array}{l} \pm \text { SD): } 7.416 \pm 0.634 \\
.010, p=0.424\end{array}$ & & \\
\hline & & & & Multiple regression weight & \\
\hline & & Correlation coefficient & $\mathrm{b}$ & & $\beta$ \\
\hline & & -0.091 & 0.001 & & 0.018 \\
\hline Menc & tion & -0.140 & -0.016 & & -0.202 \\
\hline & & -0.068 & -0.023 & & -0.103 \\
\hline & & 0.155 & 0.235 & & 0.170 \\
\hline Hereditary ter & ards fracture & 0.020 & 0.004 & & 0.002 \\
\hline & & 0.090 & 0.053 & & 0.042 \\
\hline & & $\begin{array}{r}\text { Social function sc } \\
R^{2}=0.171, F(6\end{array}$ & $\begin{array}{l}\text { SD): } 31.979 \pm 4.572 \\
.061, \mathrm{p}=0.009\end{array}$ & & \\
\hline & & Correlation coefficient & & Multiple regression weight & \\
\hline & & Correlation coefficient & $\mathrm{b}$ & & $\beta$ \\
\hline & & -0.074 & $-0.290^{*}$ & & -0.479 \\
\hline Menc & tion & 0.019 & 0.188 & & 0.316 \\
\hline & & $-0.264^{*}$ & -0.292 & & -0.180 \\
\hline & & 0.087 & 0.720 & & 0.071 \\
\hline Hereditary ter & ards fracture & 0.007 & 0.937 & & 0.049 \\
\hline Fra & & $0.276^{*}$ & $2.548^{*}$ & & 0.273 \\
\hline & & $\begin{array}{r}\text { Health perception } \\
\mathrm{R}^{2}=0.143, \mathrm{~F}(6,\end{array}$ & $\begin{array}{l} \pm S D): 32.677 \pm 6.356 \\
.474, p=0.029\end{array}$ & & \\
\hline & & Cormelation coffirent & & Multiple regression weight & \\
\hline & & Correlation coemcient & $\mathrm{b}$ & & $\beta$ \\
\hline & & 0.116 & -0.133 & & -0.161 \\
\hline Menc & tion & 0.137 & 0.144 & & 0.178 \\
\hline & & -0.162 & 0.016 & & 0.007 \\
\hline & & 0.042 & 0.230 & & 0.017 \\
\hline Hereditary ter & ards fracture & $-0.273^{*}$ & $-6.495^{*}$ & & -0.250 \\
\hline & & $0.277^{*}$ & 3.185 & & 0.251 \\
\hline & & $\begin{array}{r}\text { Mental function sc } \\
\mathrm{R}^{2}=0.102, \mathrm{~F}(6\end{array}$ & $\begin{array}{l}\text { SD): } 30.604 \pm 2.568 \\
585, p=0.134\end{array}$ & & \\
\hline & & Corrolation cenfficiont & & Multiple regression weight & \\
\hline & & Correlation coefficient & $\mathrm{b}$ & & $\beta$ \\
\hline & & -0.143 & -0.083 & & -0.240 \\
\hline Meno & tion & -0.048 & 0.064 & & 0.187 \\
\hline & & -0.164 & $-0.220^{*}$ & & -0.235 \\
\hline & & $-0.170^{*}$ & -0.360 & & -0.062 \\
\hline Hereditary ter & ards fracture & 0.042 & 0.968 & & 0.088 \\
\hline & & -0.145 & -0.887 & & -0.165 \\
\hline
\end{tabular}


Table 2. Participants' osteodensitometric and biochemical parameters $(\mathrm{X} \pm \mathrm{SD})$.

\begin{tabular}{|c|c|c|c|c|c|c|c|c|c|}
\hline $\begin{array}{c}\mathrm{BMD} \\
\mathrm{LV}\left(\mathrm{gr} / \mathrm{cm}^{2}\right)\end{array}$ & $\begin{array}{l}\text { T score } \\
\text { LV (SD) }\end{array}$ & $\begin{array}{c}\mathrm{BMD} \\
\mathrm{FN}\left(\mathrm{gr} / \mathrm{cm}^{2}\right)\end{array}$ & $\begin{array}{l}\text { T score } \\
\text { FN (SD) }\end{array}$ & $\begin{array}{c}\text { FRAX } \\
\operatorname{MOF}(\%)\end{array}$ & $\begin{array}{c}\text { FRAX } \\
\text { FNF (\%) }\end{array}$ & Vit D (ng/ml) & $\mathrm{Ca}(\mathrm{mmol} / \mathrm{l})$ & $\mathrm{P}(\mathrm{mmol} / \mathrm{l})$ & $\operatorname{ALP}(\mathrm{U} / \mathrm{l})$ \\
\hline $0.74 \pm 0.09$ & $-2.65 \pm 0.94$ & $0.69 \pm 0.10$ & $-2.14 \pm 1.30$ & $12.29 \pm 10.94$ & $3.24 \pm 7.46$ & $21.31 \pm 6.05$ & $2.31 \pm 0.21$ & $1.18 \pm 0.25$ & $70.09 \pm 14.92$ \\
\hline
\end{tabular}

Table 3. Correlations between clinical parameters and QUELEFFO-41 domains in 100 osteoporotic patients (†Adjusted for age, menopause duration, BMI, smoking habits, hereditary tendency towards fracture and fracture history; $p<0.05)$.

\begin{tabular}{|c|c|c|c|c|c|c|c|c|c|c|c|}
\hline $\begin{array}{l}\text { QUALEFFO-41 } \\
\text { domain }\end{array}$ & $\begin{array}{l}\text { Correla- } \\
\text { tion } \\
\text { coefficient }\end{array}$ & $\begin{array}{l}\text { BMD } \\
\text { LV }\end{array}$ & $\begin{array}{l}\text { T score } \\
\text { LV }\end{array}$ & $\begin{array}{l}\text { BMD } \\
\text { FN }\end{array}$ & $\begin{array}{l}\text { T score } \\
\text { FN }\end{array}$ & $\begin{array}{l}\text { FRAX } \\
\text { MOF }\end{array}$ & $\begin{array}{l}\text { FRAX } \\
\text { FNF }\end{array}$ & Vit D & $\mathrm{Ca}$ & $\mathrm{P}$ & ALP \\
\hline \multirow{2}{*}{ Pain } & Crude & $-0.224 \%$ & $-0.283^{*}$ & 0.144 & 0.004 & $0.270^{*}$ & 0.130 & -0.106 & 0.101 & -0.243 & -0.015 \\
\hline & Adjusted $^{+}$ & -0.090 & -0.042 & $0.331^{*}$ & $0.449^{*}$ & -0.155 & -0.094 & -0.090 & -0.042 & $0.331^{*}$ & $0.449^{*}$ \\
\hline \multirow{2}{*}{$\begin{array}{l}\text { Physical } \\
\text { function }\end{array}$} & Crude & -0.074 & -0.147 & -0.004 & -0.039 & 0.087 & 0.087 & 0.222 & -0.233 & $-0.414^{*}$ & -0.062 \\
\hline & Adjusted $^{+}$ & -0.141 & -0.096 & -0.045 & -00.050 & 0.143 & 0.101 & -0.141 & -0.096 & -0.045 & -0.050 \\
\hline \multirow{2}{*}{$\begin{array}{l}\text { Social } \\
\text { function }\end{array}$} & Crude & -0.113 & -0.195 & $0.345^{*}$ & $0.317^{*}$ & -0.066 & -0.095 & 0.002 & $0.304^{*}$ & -0.263 & -0.135 \\
\hline & Adjusted $^{+}$ & -0.069 & 0.025 & $0.422^{*}$ & $0.419^{*}$ & -0.205 & -0.144 & -0.069 & 0.025 & $-0.422^{*}$ & $0.419^{*}$ \\
\hline \multirow{2}{*}{$\begin{array}{l}\text { Health } \\
\text { perception }\end{array}$} & Crude & -0.097 & -0.092 & 0.189 & 0.009 & 0.069 & -0.061 & -0.137 & -0.026 & 0.163 & 0.065 \\
\hline & Adjusted $^{+}$ & -0.027 & -0.043 & 0.176 & $0.434^{*}$ & $-0.363^{*}$ & $-0.277^{*}$ & -0.027 & -0.043 & 0.176 & $0.434^{*}$ \\
\hline \multirow{2}{*}{$\begin{array}{l}\text { Mental } \\
\text { function }\end{array}$} & Crude & $-0.221^{*}$ & -0.187 & 0.198 & 0.162 & $-0.226^{*}$ & -0.154 & $-0.418^{*}$ & $0.263^{*}$ & $-0.380^{*}$ & $-0.302^{*}$ \\
\hline & Adjusted $^{+}$ & $-0.245^{*}$ & $-0.253^{*}$ & 0.166 & $0.252^{*}$ & $-0.259^{*}$ & -0.165 & $-0.245^{*}$ & $0.253^{*}$ & 0.166 & $0.252^{*}$ \\
\hline
\end{tabular}

score LV and BMD LV and was positively correlated with FRAX MOF; however, these correlation coefficients were very low and were not statistically significant following adjustment for possible confounding variables (basic patient characteristics). However, after adjustment for basic patient characteristics, BMD FN, T score FN and P and ALP levels exhibited significant positive correlations with Pain scores, and the strength of the linear relationship was fair (correlation coefficient value 0.3-0.5).

Physical function domain scores were significantly negatively correlated with P levels, and the strength of the correlation coefficient was fair; however, after adjustment for confounding variables, this correlation lost its significance.

Social function domain scores were significantly positively correlated with BMD FN, T score FN and Ca levels. After adjustment, the correlation coefficients pertaining to the relationships between the Social function domain and BMD FN and T score FN increased, while Ca levels were found to have a non-significant correlation with this QUELEFFO-41 domain. Furthermore, after adjustment for confounding variables, $P$ and ALP exhibited significant positive correlations with the Social function domain, and the strengths of these correlation coefficients were fair.

Before adjustment for confounding variables, Health perception scores were not significantly correlated with any osteodensitometric or biochemical variables; however, after adjustment for confounding variables, $\mathrm{T}$ score $\mathrm{FN}$ and ALP were positively correlated with the Social function domain (fair correlation strength), and FRAX MOF and FRAX FNF were negatively correlated with the Social function domain (low to fair correlation strength).

Finally, Mental function domain scores were significantly negatively correlated with BMD LV, FRAX MOF and Vit D, P, and ALP levels and positively correlated with
$\mathrm{Ca}$ (poor to fair correlation strength). After adjustment for confounding factors, the correlation coefficients pertaining to the relationships between Mental function and the indicated osteodensitometric and biochemical parameters (BMD LV, T score LV, T score FN, FRAX MOF, and Vit D, $\mathrm{Ca}$, ALP levels) were poor.

\section{DISCUSSION}

HRQoL represents an aspect of QoL that is related to patient physical, emotional, and social well-being. Previous studies have shown that HRQoL is generally impaired in women who are being treated for postmenopausal osteoporosis, but the extent to which HRQoL correlates with different clinical parameters has not been determined. Thus, the aim of our research was to evaluate the relationships between clinical (osteodensitometric and biochemical) osteoporosis markers and various HRQoL domains and to evaluate the influences of basic patient characteristics (age, BMI, and fracture history) on HRQoL.

The results of our study showed that some of the six basic participant characteristics (age, menopause length, body mass index, smoking habits, hereditary tendency toward fracture, fracture history) were significantly correlated with some QUELEFFO-41 domains; however, with the exception of the correlation between fracture history and pain score, those correlations were very weak (correlation coefficients lower than 0.3). The correlation coefficient pertaining to the relationship between fracture histories and Pain scores was 0.638 , indicating that this relationship was moderately strong. This was confirmed by multiple regression analysis, which showed that fracture history had a significantly positive regression weight; thus, if the 
other five variables remained constant, having a fracture would increase the pain score by approximately twenty points (i.e., patients with fractures would tend to exhibit worse pain scores). This finding is consistent with those of a study by Bianchi et al. (13), who reported that $66 \%$ of osteoporotic women with history of fracture reported pain, while $40 \%$ of women who have never experienced a fracture reported pain. This is understandable, as pain caused by a vertebral fracture may last for three years or more $(31,32)$ because vertebral fractures cannot be repaired and can cause permanent spinal deformities. Hip fracture, the most serious osteoporotic fracture (2), is even more painful. Furthermore, hip fracture is associated with a slow and often incomplete recovery (33).

Fracture history was also significantly correlated with the Social function and Health perception domains in our study, although the strengths of these correlations were weaker than that of the correlation between fracture history and the Pain domain. These results are consistent with those of numerous other studies showing that among patients with postmenopausal osteoporosis, women who have previously experienced fractures have lower HRQoL than women who have not experienced fractures (34-38). For example, Guillemin and colleagues (39) explored how a range of clinical characteristics may contribute to reductions in HRQoL and showed that previous fractures were associated with lower health utility scores by $10.3 \%$ and that fear of falling, which may induce fractures, was also significantly related to worse HRQoL. Osteoporotic fractures affect the musculoskeletal system and cause chronic pain, functional disability, mood changes and HRQoL impairment, but knowledge of an increased fracture risk can also affect the daily activities and HRQoL of subjects with low BMD (9). Pain, which may exist even before fractures occur, as well as numerous other comorbidities, may be responsible for this. These patients are deeply worried and anxious and consequently experience psychosocial behaviour changes resulting in depression and low self-esteem, which have negative effects on health perception (40).

The possibility that HRQoL may be affected by low BMD has not been extensively investigated, and many studies do not differentiate between osteoporosis (low BMD) and fracture. Many cross-sectional prospective population studies indicate that the risk of fracture increases by a factor of 1.5 to 3.0 for each standard deviation decrease in BMD (41). However, although bone mass is an important component of fracture risk, several risk factors, such as age, BMI, previous fragility fractures, parental hip fracture history, rheumatoid arthritis, glucocorticoid use, and active cigarette smoking, must also be taken into account (5). Thus, we attempted to determine the correlations between BMD, T score and FRAX index and patient HRQoL. Previously, Bianchi et al. showed that the correlations between BMD $\mathrm{T}$ scores and QUALEFFO-41 scores were significant after adjustment for age, social status (e.g., education, marriage, and living alone or not) and lifestyle habits (e.g., smoking and drinking) in osteoporotic patients and that the correlations between BMD T scores and the Physical function, Social function and Health perception domains were independent of the presence of fractures (13). Correlation analysis in our study showed that correlation coefficients increased in most cases when the correlations between osteodensitometric parameters and HRQoL were adjusted for possible confounding variables (basic participant characteristics). However, those coefficients were still poor $(<0.3)$ or fair $(0.3-0.5)$. The highest correlation coefficients pertained to the relationships between BMD FN and T score FN and Pain, Social function and Health perception scores. Wilson's analysis reported that four out of six data sets pertaining to the relationship between HRQoL and BMD of the upper femur demonstrated significant associations between these parameters (9). Additionally, multivariate analysis performed in a study by Romagnoli et al. showed that BMD of the upper femur was associated with Physical function and Health perception scores, as well as total QUALEFFO-41 scores (10). The association between BMD of the lumbar spine and HRQoL was previously reported in only one study and only in the control group (15). The absence of a correlation between HRQoL and BMD of the lumbar spine in previous studies may be explained by the incidence of degenerative change in the lumbar spine region, which can cause artificial increases in BMD, as measured by DXA (42).

Vitamin D insufficiency and deficiency are directly associated with various morbidities in elderly people (24); however, little is known regarding the relationship between serum vitamin D levels and HRQoL in osteoporosis. Although there is no consensus regarding optimal vitamin $\mathrm{D}$ levels, it is recommended that patients maintain serum vitamin D levels of more than $30 \mathrm{ng} / \mathrm{ml}$ to ensure maximum calcium absorption and optimal health (23). Levels below $20 \mathrm{ng} / \mathrm{ml}$ are considered vitamin D insufficiency, while levels below $12 \mathrm{ng} / \mathrm{ml}$ are considered vitamin D deficiency (5). Several studies have found that more than $50 \%$ of patients with osteoporosis have inadequate vitamin D levels (19). A systematic review regarding vitamin D inadequacy among postmenopausal women reported ranges of $12.5-76 \%$ for vitamin D deficiency and 1.6-86 \% for vitamin D insufficiency among osteoporotic women (43). Given the role of vitamin D in bone metabolism (17), as well as the effects of vitamin D on the neuromuscular system $(44,45)$, the absence of strong literature data regarding the relationship between its levels and osteoporotic patient HRQoL is surprising. Few subjects in recent years have been the source of as much discussion in the medical community as vitamin D; thus, we included its measurement in our study. Furthermore, we included the measurements of other important bone health-related biochemical parameters, such as minerals (calcium and phosphorus) and the enzyme alkaline phosphatase, a marker of bone formation.

A recently published study by Ohta and coworkers (28) reported that serum vitamin $D$ levels were a significant determinant of QoL in osteoporotic women independent of the conventional factors that reduce QoL. The results of 
our study showed that vitamin D levels were significantly correlated with only Mental function, both before and after adjusting for potential confounding variables. This finding is consistent with those of some previous studies, as vitamin D deficiency has been shown to be related to depression, which may contribute to decreases in QoL (19). Basaran and coworkers also reported a significant relationship between vitamin D and Physical function (19), which was not noted in our study. Generally, many studies have shown associations between vitamin D and physical functions $(46,47)$, but few have directly investigated the relationship between vitamin D status and HRQoL in osteoporosis patients.

More than $99 \%$ of $\mathrm{Ca}$ and $80-85 \%$ of $\mathrm{P}$ in the human body are located in bones; however, these elements may also be found in blood and cells and play multiple important roles elsewhere in the body (48). For instance, Ca plays an important role in neuromuscular activity, while P plays an important role in energy metabolism. Thus, we hypothesized that the levels of these elements may be correlated with Physical function scores. In our study, Physical function scores correlated significantly (negatively) with only P levels; however, after adjustment for basic characteristics, this relationship lost its significance. Although Ca plays a role in both pain and antinociception (49), it was not correlated with Pain scores, while $\mathrm{P}$ and ALP, after adjustment for potential confounding variables, were positively correlated with Pain, and the strength of the correlation coefficient was fair. Correlation analysis suggested that patients with higher P levels exhibited better mental and psychosocial health, while patients with higher serum Ca levels exhibited worse mental and psychosocial health. In the general population, high serum $\mathrm{Ca}$ levels are associated with faster declines in cognitive function in individuals over the age of 75 (50), which may explain the positive correlations between $\mathrm{Ca}$ and Mental and Social function. The correlation coefficients for the abovementioned relationships ranged from poor to fair $(r \approx 0.2-0.4)$, which may be explained by the ages of our subjects and the fact that all of the biochemical parameters of our subjects were within their reference ranges. The strongest correlation coefficients $(r \approx 0.4-0.5)$ between biochemical parameters and quality of life that were noted in our study were those pertaining to the relationship between ALP, an important marker of bone formation (51), and Pain, Health perception, Social function and Mental function. Our results indicate that after adjustment for basic subject characteristics, higher ALP levels were correlated with worse Pain, Health perception, Social function and Mental function scores. Ross et al. (52) showed that mean baseline serum bone ALP levels were significantly higher among women with a history of osteoporotic fracture than among women without a history of fracture and that in separate age-adjusted logistic regression models, serum bone ALP and calcaneus BMD were each significantly associated with new fractures. The results of that investigation indicated that increased bone turnover is significantly associated with an increased risk of osteoporotic fracture in postmenopausal women and that this association is similar in magnitude to and independent of the association between BMD and QUALEFO-41 domains (52). Thus, the positive correlations between ALP and QUALEFFO-41 domains that were observed in this study are similar to those observed between BMD FN and T score FN and QUALEFFO-41 domains and thus seem logical.

Our study included a limited number of patients compared to larger multinational investigations, but it is among first to explore this public burden in our country. This is important, as nutrition varies differently among races and geographical areas, and dietary intake of minerals and vitamins, especially $\mathrm{Ca}, \mathrm{P}$ and vitamin $\mathrm{D}$, is important for bone metabolism.

Our study confirmed the existence of a previously established relationship between BMD of the femoral neck and HRQoL in patients with osteoporosis and demonstrated correlations between blood biochemical bone metabolism parameters and HRQoL that have not been previously investigated.

The findings of our study highlight the need to include HRQoL measures in evaluations of the risk-benefit profiles of osteoporosis medications, as well as in fracture prevention programs. HRQoL should be included in comprehensive assessments of the costs of osteoporosis, including the costs associated with fracture-related morbidity. Differences in HRQoL should be taken into account when setting the priorities of health care programs. HRQoL assessments are useful for performing clinical trials and for assessing disease burdens.

\section{Conflicts of interest}

The authors declare that there are no conflicts of interest.

\section{REFERENCES}

1. Kanis JA, McCloskey EV, Johansson H, Cooper C, Rizzoli R, Reginster Y. European guidance for the diagnosis and management of osteoporosis in postmenopausal women. Osteoporos Int 2013; 24(1): 23-57.

2. Ström O, Borgström F, Kanis JA, Compsto, J, Cooper C, McCloskey EV, et al. Osteoporosis: burden, health care provision and opportunities in the EU. Arch Osteoporos 2011; 6(1): 59-155.

3. Wade SW, Strader C, Fitzpatrick LA, Anthony MS, O'Malley CD. Estimating prevalence of osteoporosis: examples from industrialized countries. Arch Osteoporos 2014; 9(1): 1-10.

4. Rachner TD, Khosla S, Hofbauer LC. Osteoporosis: now and the future. Lancet 2011; 377(9773): 1276-87.

5. Kanis JA. Diagnosis of osteoporosis and assessment of fracture risk. Lancet 2002; 359(9321): 1929-36. 
6. Gong B, Mandair GS, Wehrli FW, Morris MD. Novel assessment tools for osteoporosis diagnosis and treatment. Curr Osteoporos Rep 2014; 1-9.

7. Kanis JA, Oden A, Johansson H, Borgström F, Ström $\mathrm{O}$, McCloskey E. FRAX ${ }^{\odot}$ and its applications to clinical practice. Bone 2009; 44(5): 734-43.

8. Unnanuntana A, Gladnick BP, Donnelly E, Lane JM. The assessment of fracture risk. J Bone Joint Surg Am 2010; 92(3): 743-53.

9. Wilson S, Sharp CA, Davie MWJ. Health-related quality of life in patients with osteoporosis in the absence of vertebral fracture: a systematic review. Osteoporos Int 2012; 23(12): 2749-68.

10. Romagnoli E, Carnevale V, Nofroni I, D’Erasmo E, Paglia F, De Geronimo S, et al. Quality of life in ambulatory postmenopausal women: the impact of reduced bone mineral density and subclinical vertebral fractures. Osteoporos Int 2004; 15(12): 975-80.

11. Lips P, Leplege A. Development and validation of a quality of life questionnaire for patients with vertebral fractures: Qualeffo-41. Qual Life Res 2000; 9(1): 763-6.

12. Lips P, van Schoor NM. Quality of life in patients with osteoporosis. Osteoporos Int 2005; 16(5): 447-55.

13. Bianchi ML, Orsini MR, Saraifoger S, Ortolani S, Radaelli G, Betti S. Quality of life in post-menopausal osteoporosis. Health Qual Life Outcomes 2005; 3(1): 78.

14. Cohen A, Liu XS, Stein EM, McMahon DJ, Rogers HF, LeMaster J, et al. Bone microarchitecture and stiffness in premenopausal women with idiopathic osteoporosis. J Clin Endocrinol Metab 2009; 94(11): 4351-60.

15. Cvijetić S, Mestrović T, Crkvenac A, Davila S, Korsić M. Quality of life in osteoporotic patients with hip fracture and without fracture. Arh Hig Rada Toksikol 2002; 53(4): 257-62.

16. Salaffi F, Cimmino MA, Malavolta N, Carotti M, Di Matteo L, Scendoni P, et al. The burden of prevalent fractures on health-related quality of life in postmenopausal women with osteoporosis: the IMOF study. J Rheumatol 2007; 34(7): 1551-60.

17. Lips P, van Schoor NM. The effect of vitamin D on bone and osteoporosis. Best Pract Res Clin Endocrinol Metab 2011; 25(4): 585-91.

18. Lips P. Vitamin D deficiency and secondary hyperparathyroidism in the elderly: consequences for bone loss and fractures and therapeutic implications. Endocr Rev 2001; 22(4): 477-501.

19. Basaran S, Guzel R, Coskun-Benlidayi I, Guler-Uysal F. Vitamin D status: effects on quality of life in osteoporosis among Turkish women. Qual Life Res 2007; 16(9): 1491-9.

20. Mata-Granados JM, Cuenca-Acevedo JR, de Castro ML, Holick MF, Quesada-Gómez JM. Vitamin D insufficiency together with high serum levels of vitamin A increases the risk for osteoporosis in postmenopausal women. Arch Osteoporos 2013; 8(1-2): 1-8.

21. Holick MF. Vitamin D deficiency. N Engl J Med 2007; 357(3): 266-81.
22. Rizzoli R, Boonen $S$, Brandi $M L$, Bruyère $O$, Cooper $C$, Kanis JA, et al. Vitamin D supplementation in elderly or postmenopausal women: a 2013 update of the 2008 recommendations from the European Society for Clinical and Economic Aspects of Osteoporosis and Osteoarthritis (ESCEO). Curr Med Res Opin 2013; 29(4): 305-13.

23. Reginster JY. The high prevalence of inadequate serum vitamin D levels and implications for bone health. Curr Med Res Opin 2005; 21(4): 579-85.

24. Rosen CJ, Adams JS, Bikle DD, Black DM, Demay MB, Manson JE, et al. The nonskeletal effects of vitamin D: an Endocrine Society scientific statement. Endocr Rev 2012; 33(3): 456-92.

25. Bischoff-Ferrari HA, Giovannucci E, Willett WC, Dietrich T, Dawson-Hughes B. Estimation of optimal serum concentrations of 25-hydroxyvitamin D for multiple health outcomes. Am J Clin Nutr 2006; 84(1): 18-28.

26. Janssen HC, Samson MM, Verhaar HJ. Vitamin D deficiency, muscle function, and falls in elderly people. Am J Clin Nutr 2002; 75(4): 611-5.

27. Montero-Odasso M, Duque G. Vitamin D in the aging musculoskeletal system: an authentic strength preserving hormone. Mol Aspects Med 2005; 26(3): 203-19.

28. Ohta H, Uemura Y, Nakamura T, Fukunaga M, Ohashi Y, Hosoi T, et al. Serum 25-hydroxyvitamin D level as an independent determinant of quality of life in osteoporosis with a high risk for fracture. Clinl Ther 2014; 36(2): 225-35.

29. Tadic I, Vujasinovic Stupar N, Tasic L, Stevanovic D, Dimic A, Stamenkovic B, et al. Validation of the osteoporosis quality of life questionnaire QUALEFFO-41 for the Serbian population. Health Qual Life Outcomes 2012; 18(10): 1.

30. http://www.shef.ac.uk/FRAX. Accessed 20 May 2014.

31. Ross PD, Davis JW, Epstein RS, Wasnich RD. Pain and disability associated with new vertebral fractures and other spinal conditions. J Clin Epidemiol1994; 47(3): 231-9.

32. Ross PD. Clinical consequences of vertebral fractures. Am J Med 1997; 103(2): S30-43.

33. Lips P, Cooper C, Agnusdei DF, Caulin F, Egger P, Johnell $\mathrm{O}$, et al. Quality of life in patients with vertebral fractures: validation of the quality of life questionnaire of the European Foundation for Osteoporosis (QUALEFFO). Osteoporos Int 1999; 10(2): 150-60.

34. Adachi JD, Ioannidis G, Olszynski WP, Brown JP, Hanley DA, Sebaldt RJ, et al. The impact of incident vertebral and non-vertebral fractures on health related quality of life in postmenopausal women. BMC Musculoskelet Disord 2002; 3: 11

35. Randell AG, Nguyen TV, Bhalerao N, Silverman SL, Sambrook PN, Eisman JA. Deterioration in quality of life following hip fracture: a prospective study. Osteoporos Int 2000; 11: 460-6

36. Oleksik A, Lips P, Dawson A, Minshall ME, Shen W, Cooper C, et al. Health-related quality of life in postmenopausal women with low BMD with or without prevalent vertebral fractures. Journal of bone and mineral research 2000; 15(7): 1384-92. 
37. Silverman SL, Minshall ME, Shen W, Harper KD, Xie S. The relationship of health-related quality of life to prevalent and incident vertebral fractures in postmenopausal women with osteoporosis: results from the Multiple Outcomes of Raloxifene Evaluation Study. Arthritis Rheum 2001; 44: 2611-9.

38. Rostom S, Allali F, Bennani L, Abouqal R, Hajjaj-Hassouni N. The prevalence of vertebral fractures and health-related quality of life in postmenopausal women. Rheumatol Int 2012; 32(4): 971-80.

39. Guillemin F, Martinez L, Calvert M, Cooper C, Ganiats T, Gitlin M, et al. Fear of falling, fracture history, and comorbidities are associated with health-related quality of life among European and US women with osteoporosis in a large international study. Osteoporos Int 2013; 24(12): 3001-10.

40. de Oliveira Ferreira N, Arthuso M, da Silva R, Pedro AO, Neto AMP, Costa-Paiva L. Quality of life in women with postmenopausal osteoporosis: correlation between QUALEFFO 41 and SF-36. Maturitas 2009; 62(1): 85-90.

41. Marshall D, Johnell O, Wedel H. Meta-analysis of how well measures of bone mineral density predict occurrence of osteoporotic fractures. BMJ 1996; 312(7041): 1254-9.

42. Yu W, Glüer CC, Fuerst T, Grampp S, Li J, Lu Y, et al. Influence of degenerative joint disease on spinal bone mineral measurements in postmenopausal women. Calcif Tissue Int 1995; 57(3): 169-74.

43. Gaugris S, Heaney RP, Boonen S, Kurth H, Bentkover JD, Sen SS. Vitamin D inadequacy among postmenopausal women: a systematic review. QJM 2005; 98(9): 667-76.
44. Stockton KA, Mengersen K, Paratz JD, Kandiah D, Bennell KL. Effect of vitamin D supplementation on muscle strength: a systematic review and meta-analysis. Osteoporos Int 2011; 22(3): 859-71.

45. Muir SW, Montero-Odasso M. Effect of Vitamin D supplementation on muscle strength, gait and balance in older adults: a systematic review and meta-analysis. J Am Geriatr Soc 2011; 59(12): 2291-300.

46. Di Monaco M, Vallero F, Di Monaco R, Mautino F, Cavanna A. Serum levels of 25-hydroxyvitamin D and functional recovery after hip fracture. Arch Phys Med Rehabil 2005; 86(1): 64-8.

47. Di Monaco M, Vallero F, Di Monaco R, Tappero R, Cavanna A. 25-hydroxyvitamin $\mathrm{D}$, parathyroid hormone, and functional recovery after hip fracture in elderly patients. J Bone Miner Metab 2006; 24(1): 42-7.

48. Savic LJ, Savic D. Serum calcium and phosphorus concentration and alkaline phosphatase activity in healthy children during growth and development. Med Preg1 2008; LXI (7-8): 393-9.

49. Prado WA. Involvement of calcium in pain and antinociception. Braz J Med Biol Res 200; 34(4): 449-61.

50. Schram MT, Trompet S, Kamper AM, de Craen AJ, Hofman A, Euser SM, et al. Serum calcium and cognitive function in old age. J Am Geriatr Soc 2007; 55(11): 1786-92.

51. Wheater G, Elshahaly M, Tuck SP, Datta HK, van Laar JM. The clinical utility of bone marker measurements in osteoporosis. J Transl Med 2013;11:201.

52. Ross PD, Kress BC, Parson RE, Wasnich RD, Armour KA, Mizrahi IA. Serum bone alkaline phosphatase and calcaneus bone density predict fractures: a prospective study. Osteoporos Int 2000; 11(1): 76-82. 


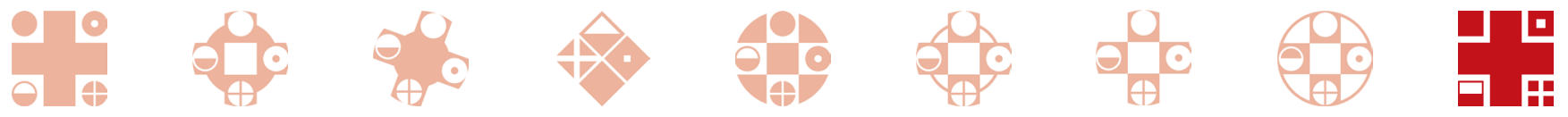

